\title{
ORGANIZATIONAL CREATIVITY IN INNOVATION - A MULTICRITERIA DECISION ANALYSIS
}

\author{
Fellipe Silva Martins \\ Universidade Nove de Julho, Brazil \\ E-mail: fellipemartins@uni9.pro.br \\ Eduardo Biagi Almeida Santos \\ Universidade Nove de Julho, Brazil \\ E-mail: eduardo.santos@uni9.pro.br \\ Leonardo Vils \\ Universidade Nove de Julho, Brazil \\ E-mail: leo.vils@uni9.pro.br \\ Submission: 03/03/2017 \\ Revision: 20/03/2017 \\ Accept: 24/04/2017
}

\section{ABSTRACT}

Creativity is essential for the emergence of innovation within organizations, both necessary for organizational survival. Several models have been proposed for organizational creativity, each containing different constructs. This research aims to verify the standardization of constructs in the literature and to verify the possible existence of two dimensions not previously explored: hierarchy between constructs (global importance) and weight of constructs (relative importance) of organizational creativity that lead to innovation. We employed Multicriteria Decision Analysis with the PAPRIKA method, which combines the advantages of numerical and verbal decision making. The creativity constructs were elicited from a detailed review of the literature from Scopus and Web of Science databases. The results contribute to the expansion of the current theory of creativity, with the application of a new method to the object and management practices.

Keywords: Organizational creativity, innovation, multi-criteria decision analysis. 
DOI: 10.14807/ijmp.v8i4.643

\section{INTRODUCTION}

Organizational creativity and innovation are jointly studied in the creative literature (WOODMAN; SAWYER; GRIFFIN, 1993; AMABILE, 1996; DILIELLO; HOUGHTON, 2008). However, there are still issues to be highlighted in this context regarding the internal organization of creativity constructs. These are studied in a generally isolated way, i.e., in a descriptive and verbal way. This research seeks to answer how the constructs of organizational creativity for innovation are organized in a hierarchical way, and especially in a measurable and integrated way.

As such, individual creativity is introduced as a facilitator of organizational innovation (WOODMAN; SAWYER; GRIFFIN, 1993), since individuals are the main implementers of creative ideas in organizations. The main dimensions present in the creativity literature are knowledge (how much the person knows about a subject), divergent thinking (related to the cognition of the individual), individual personality as well as intrinsic and extrinsic motivation (DILIELLO; HOUGHTON, 2008). However, organizations can not be dependent solely on individual creativity as a source of innovation.

Therefore, organizations leave the state of habitual creative passivity and become creative actors via fostering internal structures, management and resources geared towards creativity generation (SHALLEY; GILSON, 2004). Thus, both academia and practitioners need theoretical support to understand what criteria (constructs) are most important in the formation of creative teams in their organizations, with the goal of generating innovation (SHALLEY et al., 2004; WONGTADA; RICE, 2008).

For this, we employed a mixed verbal-quantitative mechanism, Multicriteria Decision Analysis technique (PAPRIKA - Potentially pairwise rankings of all possible alternatives) (HANSEN; OMBLER, 2008). This method allows hierarchizing constructs and allows the inference of the relative importance of each of them, in relation to the others. To support this decision method, we performed a literature review to define the constructs to be used with the PAPRIKA technique.

The criteria used to choose the articles were the number of citations; quality of journals, and focus on organizational creativity for innovation. A framework with the most relevant papers and filtered, grouped constructs was also developed. After this process, 121 questionnaires (with 88 valid answers) were obtained from specialists 
from management graduate schools in the main universities of São Paulo state (Brazil), for the creation of a hierarchical model of constructs.

This research has several contributions. First, applying a new method of Multicriteria Decision Analysis (PAPRIKA), to the subject of successful studies of creativity and innovation, which had not been previously done in Brazil. Second, the theoretical contribution as an improvement of the theoretical models of creativity when verifying the existence of the dimensions of hierarchy (global importance) and weight (relative importance) to the constructs found in the literature. Finally, the research presents practical contributions by highlighting the possibility of measuring creativity profiles in organizations.

\section{CREATIVITY}

Creativity is discussed in the literature as a production of something new by means of a restlessness in or an extrapolation of the acquired knowledge. It can be recognized as soon as people with great familiarity in a given subject have access to ideas (AMABILE et al., 1996). That is, whenever experts in the field evaluate ideas and identify them as creative. This method is called Consensus Evaluation (AMABILE et al., 1996; AMABILE, 1997).

However, identifying accomplished (or at least potentially) creative individuals is an easy task, since these stand out in the crowd. However, making these individuals cooperate or stimulate the groups for which they work is not as easy. For this reason, the bulk of the literature on creativity has been focused on circumstantial aspects, such as social and environmental influences (especially from an organizational point of view), that may alter, distort or foster creativity (AMABILE; PILLEMER, 2012).

Experiments, for instance, have shown that environments may be manipulated to alter perceptions of creativity or even produce creativity (KRUGLANSKI; FRIEDMAN; ZEEVI, 1971; TORRANCE, 1988; RUNCO; SAKAMOTO, 1999). Social ties, more specifically, may become tools for facilitating individual creativity and, at the same time, diffusing creative ideas in an organization (PERRY-SMITH, 2006).

Thus, Amabile's model of creativity (1996) offers keen insights about how to manage creativity since it splits 'creativity' in two main clusters - individual/team 
creativity and work environment. In the first, individual creativity cannot be entirely dissociated from group creativity. Although both may happen separately, organizations strive to form a continuum between individual idea generation and group creativity absorption and dissemination (HIRST; VAN KNIPPENBERG; ZHOU, 2009), as well as group creativity and idea generation (PAULUS; YANG, 2000; GARFIELD et al., 2001; GONCALO; STAW, 2006), and future innovation development and its marketing (TOUBIA, 2006).

In this model, creativity itself has three main factors (AMABILE et al., 1996). First, on needs expertise, i.e., knowledge about the subject (the technical mastery over the fact) in order to be able to go beyond what is expected. Second, creativity skills take place (knowledge, divergent thinking), which can be applied in any domain, enhancing creative performance since it is closely linked to personality, selfdiscipline, orientation beyond risk, as described by Sternberg (2006). Finally, task orientation (intrinsic / extrinsic motivation) is also relevant, which refers to the individual being motivated to perform the task is more likely to have creative ideas.

\subsection{Organizational creativity}

Organizations have a strong impact on the individual's creativity (AMABILE, 1997). Organizational creativity can be considered from the individual and team perspective as well as from the work context perspective (AMABILE, 1997). These are altered by the available resources, business practices and organizational motivation.

Organizational creativity models discuss the role of leadership in process openness (AMABILE, 1998). As such, creativity stems from the person to the process and that may finally result in a product. Individual skills, experience, personality, knowledge and motivation are factors that are related to the individual participant in the process (MOULTRIE; YOUNG, 2009).

This process refers to the stages of thinking in which people are engaged while working alone or with others (EKVALL, 1997). The environment is also an important factor in the model, if it is framed as the psychological or physiological environment in which the person works. The creative work environment is related to the characteristics in the environment that should promote openness for social, cultural and communication interaction with the goal of facilitating creative thinking and action (AMABILE, 1998). 
The culture of an organization is also a factor discussed by several authors (WESTWOOD; LOW, 2003; MOULTRIE; YOUNG, 2009) and is related to the promotion or hindrance of creativity. An organization that has a culture that allows process flexibility and has more open communication tends to be more creative. The Ekvall model (1996) discusses how an organization's culture can create creative solutions from its employees. The model is composed of ten factors: dispute, freedom, support for ideas, confidence, dynamism, humor, debates, conflicts, risk taking and idea time.

Puccio and Cabra (2010) present five important factors necessary for the organization to promote creativity: 1) The innovation strategy focuses explicitly on the development and introduction of new products and services is derived from the organization's vision; 2) Organizational structure that includes flexibility, freedom and cooperative teams; 3) Organizational support mechanisms, such as reward and recognition programs, and availability of resources; 4) Behavior that stimulates innovation, consisting of responses to failure, generation of ideas, continuous learning spirit, risk management and support for change; And 5) Open communication.

The organizational structure is seen in the literature as influential of organizational creativity (PUCCIO; CABRA, 2010; AMABILE, 1997). This factor concerns the hierarchy of the organization and how it communicates (EKVALL, 1997). The structure should be open to communication and with a favorable climate for creativity. The organizational climate refers to the structure, salaries, benefits, physical environment and dimensions of the work environment (EKVALL, 1996).

\subsection{Innovation and creativity}

According to the most advanced innovation and creativity model (AMABILE, 1996, AMABILE, 1997), three pillars are usually considered: 1) Resources - related to sufficient time to produce ideas, people with the necessary expertise, allocated funds, materials, systems and information; 2) Management Practices - management components that encourage individual development for creativity; 3) Organizational motivation - refers to the organizational tools and mechanism to extrinsically motivate employee and stimulate creativity. The literature relates the concept of creativity to the concept of innovation, showing that creativity is a necessary but not sufficient component of innovation. With this, the creation of new ideas comes to 
INDEPENDENT JOURNAL OF MANAGEMENT \& PRODUCTION (IJM\&P)

http://www.ijmp.jor.br

v. 8, n. 4, October - December 2017

ISSN: 2236-269X

DOI: 10.14807/ijmp.v8i4.643

light, with the goal of seeking to innovate in products or processes (AMABILE et al., 1996; AMABILE, 1997).

Creativity and innovation within the organizational environment are present in the processes and product development (AMABILE et al., 1996). Creativity is in the generation of ideas and innovation is present in the implementation of these ideas and in their transformation into practices and products. The combination of the two constructs may occur at the individual, team, organizational, or combination level (ANDERSON et al., 2014). Thus, it can be considered as the central point for generating ideas while innovation emphasizes the implementation of ideas. In this way, this connection between the two constructs can occur in several levels of the organization.

\section{METHOD}

The literature, as already mentioned, allows to understand that creativity is essential in innovation processes (AMABILE et al., 1996; SHALLEY, 1995), being one of the main contributors to the innovative environment in companies (MARTIN; TERBLANCHE, 2003; ZHOU; SHALLEY, 2008). In addition, creativity, as part of administrative processes, can be fostered and guided for specific purposes (SHALLEY; GILSON, 2004). A third important aspect is that, while being primordial and manageable in organizational structures, such as other resources available to teams, creativity continues to be subject to bottlenecks and organizational difficulties (SHALLEY et al., 2004; WONGTON; RICE, 2008).

For these reasons, the need to better understand the factors that lead teams to extract greater value from creative processes in innovative environments becomes evident (PATTERSON; WARP; WEST, 2004). This work has the main objective to verify the internal relation between the constructs components of creativity for contexts of innovation. To that end, we start from the premise that environments and processes of team creativity bring structural and strategic advantages for the survival and growth of companies (MCLEAN, 2005). Thus, after starting a detailed literature review, we defined two needed steps: 1) the construction of a theoretical framework, from which the constructs used in this research emerge; And 2) based on these constructs, we propose the use of Multicriteria Decision Analysis through the PAPRIKA method to evaluate the relationship between the constructs and their weights. The first step is to verify the state of the art and the sedimentation of current 
theory in organizational creativity for innovation, allowing to determine in concrete form which underlying criteria are really relevant in the context chosen (innovation). The second step is to add two new dimensions to the studies of creativity: hierarchy (global importance) and weight (relative importance) among existing constructs.

In the execution of the first step, we performed a search in the Scopus and Web of Science databases, with the terms "organizational creativity", "innovation and creativity" and their derivatives. We found 132 documents containing the research terms, but only 52 were used in the literature review (by incidence of terms and thematic convergence). Finally, 25 articles presented thematic convergence, construct homogeneity and distinction between constructs and were used in the development of the theoretical framework.

\section{THEORETICAL FRAMEWORK}

The articles drawn from the sample present divergent theories but are not inconsistent with that of Amabile et al. (1996). These are focused on that theoretical model and do not point to aspects other than organizational creativity (individual creativity, school groups, etc.) or that simply replicate the studies present in the framework in different contexts, without, however, proposing new methodological approaches or extending existing theory. As can be seen in Table 01, the concepts and their frequencies are arranged in chronological order. In order to select the final base constructs of this research, we used a simple but adequate criterion: to select only those that appear in more than half of the articles in the table. The final constructs selected were Expertise, Task Motivation, Administrative Practices, Creative Abilities and Organizational Skills. 
Table 01: Theoretical concepts and constructs

\begin{tabular}{|c|c|c|c|c|c|c|c|c|c|c|c|}
\hline Woodman, Sawyer \& Griffin (1993) & & $\mathrm{X}$ & & $\mathrm{X}$ & & $\mathrm{X}$ & & $\mathrm{X}$ & & & \\
\hline Muller (1993) & & & & $\mathrm{X}$ & & & & $\mathrm{X}$ & & & \\
\hline Amabile et al. (1996) & $X$ & & & & & $\mathrm{X}$ & & $\mathrm{X}$ & $\mathrm{X}$ & $\mathrm{X}$ & \\
\hline Farid, El-Sharkawy (1993) & & & & $\mathrm{X}$ & $\mathrm{X}$ & $\mathrm{X}$ & $\mathrm{X}$ & & $\mathrm{X}$ & $\mathrm{X}$ & \\
\hline Amabile (1997) & & $\mathrm{X}$ & & $\mathrm{X}$ & & $\mathrm{X}$ & & $\mathrm{X}$ & $\mathrm{X}$ & $\mathrm{X}$ & $\mathrm{X}$ \\
\hline Drazin, Grynn \& Kazanjian (1999) & $\mathrm{X}$ & $\mathrm{X}$ & & $\mathrm{X}$ & & & & $\mathrm{X}$ & $\mathrm{X}$ & & $\mathrm{X}$ \\
\hline West (2000) & & $\mathrm{X}$ & & $\mathrm{X}$ & & $\mathrm{X}$ & $\mathrm{X}$ & & & $\mathrm{X}$ & $\mathrm{X}$ \\
\hline Westwood \& Low (2003) & & & $\mathrm{X}$ & $\mathrm{X}$ & & $\mathrm{X}$ & & & & $\mathrm{X}$ & \\
\hline Jaskyte \& Kisieliene (2006) & & & & $\mathrm{X}$ & & $\mathrm{X}$ & & $\mathrm{X}$ & & $\mathrm{X}$ & $\mathrm{X}$ \\
\hline George (2007) & & & & $\mathrm{X}$ & & & & $\mathrm{X}$ & & & $\mathrm{X}$ \\
\hline DiLiello \& Houghton (2008) & & $\mathrm{X}$ & & & & $\mathrm{X}$ & $\mathrm{X}$ & $\mathrm{X}$ & & $\mathrm{X}$ & \\
\hline Klijn (2009) & $\mathrm{X}$ & $\mathrm{X}$ & & $\mathrm{X}$ & & $\mathrm{X}$ & & $\mathrm{X}$ & & $\mathrm{X}$ & $\mathrm{X}$ \\
\hline Moultrie \& Yong (2009) & & $\mathrm{X}$ & & $\mathrm{X}$ & & $\mathrm{X}$ & & $\mathrm{X}$ & & $\mathrm{X}$ & $\mathrm{X}$ \\
\hline $\begin{array}{l}\text { Miron-Spektor, Erez \& Naveh } \\
\text { (2011) }\end{array}$ & $\mathrm{X}$ & $\mathrm{X}$ & & $\mathrm{X}$ & & $\mathrm{X}$ & & $\mathrm{X}$ & & $\mathrm{X}$ & \\
\hline Tuori \& Vilén (2011) & & $\mathrm{X}$ & & $\mathrm{X}$ & & $\mathrm{X}$ & & $\mathrm{X}$ & & & \\
\hline Madjar, Greenberg \& Chen (2011) & $\mathrm{X}$ & & & $\mathrm{X}$ & $\mathrm{X}$ & $\mathrm{X}$ & & $\mathrm{X}$ & $\mathrm{X}$ & & $\mathrm{X}$ \\
\hline $\begin{array}{l}\text { Sousa, Pellissier \& Monteiro } \\
\text { (2012) }\end{array}$ & & & & $\mathrm{X}$ & & & & & $\mathrm{X}$ & $\mathrm{X}$ & \\
\hline Parjanen (2012) & & $\mathrm{X}$ & & $\mathrm{X}$ & & $\mathrm{X}$ & $\mathrm{X}$ & $\mathrm{X}$ & $\mathrm{X}$ & $\mathrm{X}$ & \\
\hline Bedani (2012) & $\mathrm{X}$ & $\mathrm{X}$ & & $\mathrm{X}$ & & $\mathrm{X}$ & $\mathrm{X}$ & $\mathrm{X}$ & & $\mathrm{X}$ & \\
\hline Girdauskiene (2013) & & $\mathrm{X}$ & & & & $\mathrm{X}$ & & & $\mathrm{X}$ & $\mathrm{X}$ & \\
\hline Sacchetti \& Tortiac(2013) & & $\mathrm{X}$ & & $\mathrm{X}$ & $\mathrm{X}$ & $\mathrm{X}$ & $\mathrm{X}$ & & & $\mathrm{X}$ & $\mathrm{X}$ \\
\hline Motlagh \& Hassani (2013) & & & & & $\mathrm{X}$ & $\mathrm{X}$ & & $\mathrm{X}$ & & $\mathrm{X}$ & \\
\hline Anderson, Potočnik \& Zhou (2014) & & $\mathrm{X}$ & & $\mathrm{X}$ & & & & $\mathrm{X}$ & & $\mathrm{X}$ & \\
\hline Boada-Grau et al. (2014) & & & & $\mathrm{X}$ & $\mathrm{X}$ & $\mathrm{X}$ & & & & $X$ & \\
\hline TOTAL & 6 & 14 & 1 & 19 & 5 & 18 & 6 & 17 & 8 & 17 & 9 \\
\hline
\end{tabular}

Source: elaborated by authors

The second step of the methodology is to use the constructs as substrate of the PAPRIKA method, to consider the relation between them. In general, the direct comparison between constructs is done in an unadjusted way (CRONBACH; MEEHL, 1955). However, according to Kohli \& Jaworski (1990), numerical comparison, when performed objectively by means of quantifiable attributes (weight assignment), is not only recommended, but essential to understand the relation between constructs. However, as the number of constructs and their interrelations increases, the complexity of the model also increases exponentially (SAATY; VARGAS, 2012). Another frequent problem in decision-making about relative importance between constructs or concepts is that often quick decisions are made automatically, emotionally, and stereotyped, rather than slowly, logically, calculatingly, and primarily consciously (KAHNEMAN, 2011). 
INDEPENDENT JOURNAL OF MANAGEMENT \& PRODUCTION (IJM\&P)

http://www.ijmp.jor.br

v. 8, n. 4, October - December 2017

ISSN: 2236-269X

DOI: 10.14807/ijmp.v8i4.643

With the emergence of Multicriteria Decision Analysis (ADMC) methods, conflicts and inconsistencies in the creation of unified profiles of multiple isolated constructs (KÖKSALAN; WALLENIUS; ZIONTIS, 2011) were solved. These methods are able to select the weights, orders and how the constructs organize themselves (MAXWELL; JEFFREY; LÉVESQUE, 2011). ADMC methods, in particular the MAUT (Multiattribute Utility Theory) family, have in common the concept of trade-off or balanced exchange, in which it is sought to find, through weighted averages, the importance equivalence value of a Construct in front of the others. For Steele et al. (2009), we can measure these trade-offs using the utility function $U\left(O_{i}\right)$, whose formula is $U\left(O_{i}\right)=\sum_{k=1}^{M} Z_{k}\left(O_{i}\right) \times w\left(C_{k}\right)$, composed by $Z_{k}\left(O_{i}\right)$, which is the normalization of the score of the level $O_{i}$ according to the construct $C_{k}$ and by $w\left(C_{k}\right)$ which is the normalized weight of the construct $C_{k}$.

Related to MAUT methods is the PAPRIKA method (Potential pairwire rankings of all possible alternatives) (HANSEN; OMBLER, 2008). This method is based on the principle and mathematical mechanical characteristics of the MAUT (Multiattribute Utility Theory) methods, which use utility function to find the hierarchy between constructs. However, it uses the distribution of internal constructs as verbal descriptors, as Verbal Decision Analysis (LARICHEV; MOSHKOVICH, 1997; LARICHEV, 2001).

Among the several advantages of maintaining MAUT mechanics with a verbal decision layer is that the decision-maker (interviewee) should stick to verbal values choosing the best pair of alternatives. In pure numerical methods (MAUT, among others), in addition to choosing the pair, the decision maker has to numerically estimate the distance of relative importance between the constructs, which leads to two problems: underestimation and / or overestimation of the weight of the constructs, which may entail distortions in them (LARICHEV, 1992). An additional advantage is that PAPRIKA allows experts in the subject, who do not have ADMC training or experience, to make hierarchical decisions easily and with little commitment to instrument accuracy. Another relevant aspect of the method choice is that it has been used successfully in the creation of a hierarchy between constructs in studies in the world and well as locally (MARTINS; VANALLE; LUCATO, 2013; MARTINS; LUCATO, 2014). 
In a simplified way, the PAPRIKA method works by separating dominated pairs from non-dominated pairs. That is, take two concepts $A$ and $B$ and divide each one into levels of importance from 1 to 2 (the greater, more important), so that there are 4 possibilities: $A 1 \downarrow, A 2 \uparrow, B 1 \downarrow$ and $B 2 \uparrow$. If it is necessary to choose between $A 1 \downarrow$ $+B 1 \downarrow$ versus $A 2 \uparrow+B 2 \uparrow$, it is said to be a dominated pair, that is, an alternative (A2 $\uparrow$ $+\mathrm{B} 2 \uparrow$, with two high criteria) is intrinsically better than another (A1 $\downarrow+\mathrm{B} 1 \downarrow$, with two low criteria), because in both criteria they perform better. Thus, a decision on this type of pair is unnecessary and the dominated pairs are not presented to the decision maker.

On the other hand, if it is necessary to choose between $\mathrm{A} 1 \downarrow+\mathrm{B} 2 \uparrow$ and $\mathrm{B} 1 \downarrow+$ $A 2 \uparrow$, there is a non-dominated pair, in which only the expert's choice will be able to decide. If most experts choose $B 1 \downarrow+A 2 \uparrow$, the relation $A>B$ is created. Then imagine that there is a third criterion $C$ and each of the three criteria is divided into three levels. To avoid unresolvable tautological scenarios ( $A>B>C>A$ ), PAPRIKA tests all potentially unpaired pairs (hence their name) and uses the mathematical property of transitivity to eliminate ambiguities (if $A>B$ and $B>C$, therefore $A>C$ ), so that in the end the hierarchical order of the constructs is obtained.

Bringing this example to reality, it is necessary to replace the criteria $(A, B, C$, etc.) with constructs (Expertise, Task Motivation, etc.) and create sub-levels that emulate the mere estimation of importance distance. Since the constructs were previously surveyed through bibliometric research, it was necessary to create a comprehensive construct definition (which included the individual definitions of the constructs found in each article) and to divide them into sub-levels as shown in Table 2. 
INDEPENDENT JOURNAL OF MANAGEMENT \& PRODUCTION (IJM\&P)

http://www.ijmp.jor.br

v. 8, n. 4, October - December 2017

ISSN: 2236-269X

DOI: 10.14807/ijmp.v8i4.643

Table 02: Evaluated constructs and sublevels.

\begin{tabular}{|c|c|c|}
\hline Construct & Level & Description \\
\hline \multirow{3}{*}{ Expertise } & High & $\begin{array}{l}\text { Team has extensive knowledge about business, industry, etc., having deep technical skills } \\
\text { and conditions to create and expand existing knowledge as a natural consequence of their } \\
\text { specialization. }\end{array}$ \\
\hline & Medium & $\begin{array}{l}\text { The team has standard knowledge regarding business, industry, etc., and technical ability, } \\
\text { being able to superficially change the existing knowledge as a consequence of their } \\
\text { experience. }\end{array}$ \\
\hline & Low & $\begin{array}{l}\text { Team has little knowledge about business, industry, etc., having limited technical field, not } \\
\text { being able to create and expand existing knowledge, because they do not have experience } \\
\text { or specialization. }\end{array}$ \\
\hline \multirow{3}{*}{ Task motivation } & High & $\begin{array}{l}\text { Team is highly motivated - i.e., able to self-motivate (because it likes the task or the } \\
\text { business) and is also easily stimulated by the organizational structure. }\end{array}$ \\
\hline & Medium & $\begin{array}{l}\text { Team is unable to motivate itself (because it is indifferent to the task or the business), but } \\
\text { can be stimulated by the organizational structure. }\end{array}$ \\
\hline & Low & $\begin{array}{l}\text { Team is not motivated - i.e. it is not able to motivate itself (because it does not like the task } \\
\text { or the business) and it is not stimulated by the organizational structure. }\end{array}$ \\
\hline \multirow{3}{*}{$\begin{array}{l}\text { Management } \\
\text { practices }\end{array}$} & High & $\begin{array}{l}\text { Administrative structure allows a high degree of freedom and autonomy, as well as the } \\
\text { choice of people and skills for the tasks, besides good planning and constant feedback as } \\
\text { part of the management system }\end{array}$ \\
\hline & Medium & $\begin{array}{l}\text { Administrative structure with a certain degree of freedom and little autonomy, whose choice } \\
\text { of people is performed for mixed reasons, in addition to inconstant planning and feedback. }\end{array}$ \\
\hline & Low & $\begin{array}{l}\text { Administrative structure without freedom and autonomy, in which the choice of people and } \\
\text { skills is performed by personal management criteria, whose management does not include } \\
\text { adequate feedback or planning. }\end{array}$ \\
\hline \multirow{3}{*}{ Creative abilities } & High & $\begin{array}{l}\text { Team constantly exceeds what is standard in science or technical development, for having } \\
\text { the skills and knowledge to employ other paths, techniques and perspectives in exploring } \\
\text { possible solutions. }\end{array}$ \\
\hline & Medium & $\begin{array}{l}\text { Team attempts to surpass what is established in science or technical development, with } \\
\text { limitations on the ability to find other ways, techniques and perspectives in the exploration of } \\
\text { possible solutions. }\end{array}$ \\
\hline & Low & $\begin{array}{l}\text { Team does not try to overcome the established in science or technical development, } \\
\text { because it does not have the capacity or knowledge to try other ways, techniques and } \\
\text { perspectives in the exploration of possible solutions. }\end{array}$ \\
\hline \multirow{3}{*}{$\begin{array}{l}\text { Organizational } \\
\text { abilities }\end{array}$} & High & $\begin{array}{l}\text { Highly flexible organization, capable of reinventing itself, modifying internal communication } \\
\text { mechanisms and recognizing, valuing and implementing ideas and carrying out a fair } \\
\text { evaluation of work. }\end{array}$ \\
\hline & Medium & $\begin{array}{l}\text { Organization has a certain degree of flexibility, but does not reinvent itself quickly, has } \\
\text { problems with communication mechanisms and is limited in recognizing, valuing and } \\
\text { implementing ideas. }\end{array}$ \\
\hline & Low & $\begin{array}{l}\text { Enclosed organization, unable to reinvent itself, with ineffective communication } \\
\text { mechanisms, unable to recognize, value and implement ideas properly and perform fair } \\
\text { evaluation of work. }\end{array}$ \\
\hline
\end{tabular}
Source: elaborated by authors.

The use of three sub-levels was employed following what was first proposed by Martins, Vanalle and Lucato (2013) and Martins e Lucato (2014). The second reason is that the division into two levels always presents one level as a zero-level (because it is a dominated pair). The third and final reason for the three-tiered division is that it is cognitively simpler (from top to bottom) to be answered, with an intermediate gradation, which facilitates the decision (BELTON; STEWART, 2002; STEWART, 2005).

The definitions and sub-levels were previously validated by a group of experts. Note that all constructs are close to each other, that is, they have convergent validity, which is common, since there is always theory overlap in the constructs. There is also clarity in the discriminant validity between constructs, which has previously been validated in the original articles or in their application in structural models. 
For the development of the questionnaire, the 1000Minds system (1000MINDS, 2016) was used. The non-dominated pairs are randomly distributed according to each decision maker's responses, in order to reduce the anchoring effect (GERARD, 1954; CARTWRIGHT, 2013). If there is tautology, the system raises new questions until it is solved. Since there are three sub-levels for five criteria, there are $3^{5}$ random possibilities (243), which makes it unfeasible to list all potential non-dominated questions generated in the system.

\section{DATA COLLECTION}

After the definition of constructs and sub-levels, a questionnaire was carried out in the 1000Minds system. After the follow-up of the answers, each specialist participated in a separate interview indicating suggestions for improvements or possible difficulties (text, concept or techniques), which were incorporated into the final version.

The refined version of the questionnaire was sent to a group of 121 invited participants, all creativity specialists and researchers from the main universities of the state of São Paulo (Brazil), in management and related areas (University of São Paulo, Mackenzie Presbyterian University, Pontifícia Universidade Católica de São Paulo, Nove de Julho University - UNINOVE, São Paulo Methodist University, and Fundação Getúlio Vargas).

Data collection was performed between 05/27 and 02/07 of 2015, with 88 valid answers (72.7\%). The average of questions (non-dominated pairs) was 45 questions.

\section{RESULTS}

Literature on creativity points to a myriad of complementary theories, which, however, find few convergent structured models. Among them, that of Amabile et al. (1996) and Woodman, Sawyer and Griffin (1993) are exemplary in combining various constructs into an understandable organized structure. After the seminal work of Amabile et al. (1996), several authors confirmed and expanded it (see Table 01), so that there was a generation of new constructs with the purpose of explaining organizational creativity. On the other hand, not all the constructs found find broad theoretical support, either because a) are new constructs not yet empirically tested, b) because they are constructs that explain specific and little relevant pieces of 
INDEPENDENT JOURNAL OF MANAGEMENT \& PRODUCTION (IJM\&P)

http://www.ijmp.jor.br

v. 8, n. 4, October - December 2017

ISSN: 2236-269X

DOI: 10.14807/ijmp.v8i4.643

models, or c) because they are highly dependent on specific contexts to the local organization or culture and, therefore, are difficult to replicate.

Despite the clear recognition of such constructs, supported by repetition and applications, they are generally treated by structurally well-designed models, but do not include dimensions of weight (relative importance) and hierarchy (global importance). That is, each construct is studied either in isolation or within a model, but without understanding the measurable importance of each of them in the models. With the application of the PAPRIKA method it is possible to show that there is clearly support to accept the existence of both dimensions cited above. As can be seen in Figure 02, there is a certain variation in the pattern of expert responses, with aa few cases being considered outliers and withdrawn from the sample. After the removal of the outliers, the set of answers demonstrates a homogeneous pattern (represented by the central black line), which corroborates to the success of the application of the method and validates the obtained results.

Figure 02: Constructs e specialist decisions.

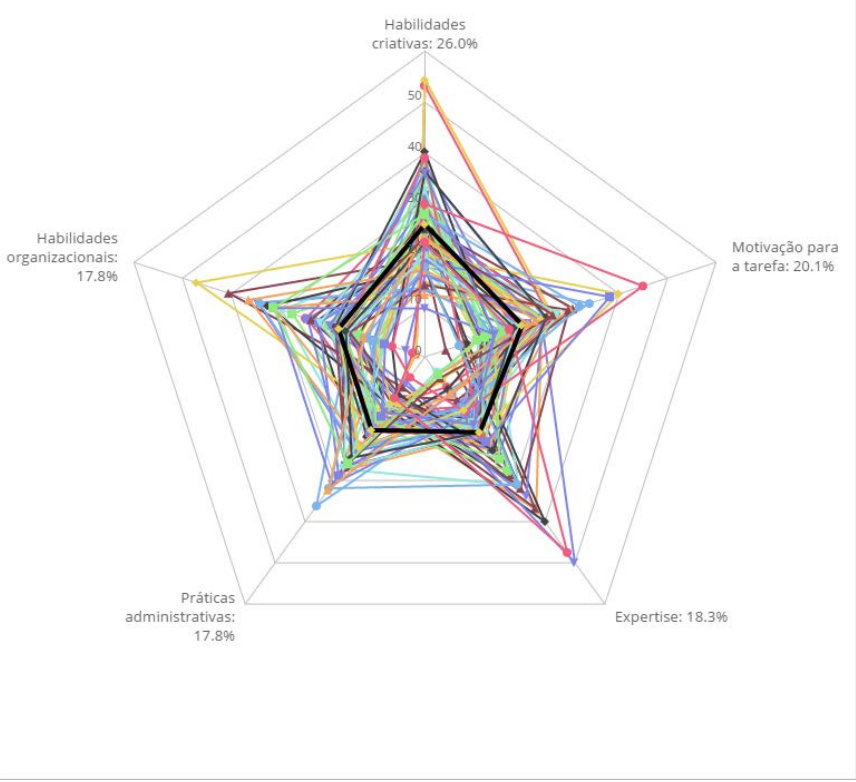

Source: Elaborated by authors

Variation in the responses is adequate (Management practices: $\mathrm{SD}=7.1 \%$; Motivation for the task: $S D=8.2 \%$; Organizational Skills: $S D=9.3 \%$; Creative Ability: SD = 9.4\%; Expertise: SD = 10.1\%), with a minimum standard deviation of $7.1 \%$ and a maximum of $10.1 \%$, which is highly acceptable in exploratory studies such as this. It should be noted that such variation in the data may be due to 
different institutions of provenance from the specialists as well as varying theories of preference of each specialist. In addition, it may be due to a certain level of ambiguity expected in numerical-verbal decision methods, due to the multiple convergent criteria and the commitment to ease of use with instrument accuracy (MOSHKOVICH; MECHITOV, 2013).

The validity of the application of the PAPRIKA method could also be verified by means of the four criteria defined by Moshkovich and Mechitov (2013), properly employed in the accomplishment of this work: a) description of the problem and criteria in natural language for the decision maker; B) procedure of identification of valid preferences (in this case by means of ranking order of importance of criteria); C) consistency preference procedure of decision makers (acceptable standard deviations); and d) transparent procedure for the decision maker (clear choice with explanation of results).

In relation to the first dimension (weight or relative importance), it can be seen, according to Table 03, that there are clearly different weights for each construct. That is, they are separable in terms of relative importance. As an example, one can choose the "Expertise" construct: this one has only $70 \%$ of the importance given to "Creative Abilities", but it has even weight and importance in the final model that, for example, "Organizational Skills" or "Management Practices".

Table 03: Utility function between constructs.

\begin{tabular}{|c|c|c|c|c|c|}
\hline & & & & \\
\hline & 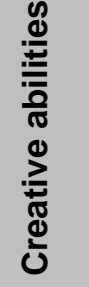 & 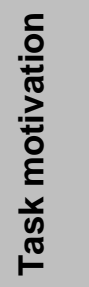 & 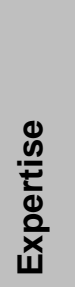 & 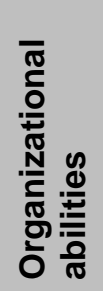 & 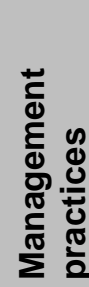 \\
\hline $\begin{array}{l}\text { Creative } \\
\text { abilities }\end{array}$ & & 1,3 & 1,4 & 1,5 & 1,5 \\
\hline Task motivation & 0,8 & & 1,1 & 1,1 & 1,1 \\
\hline Expertise & 0,7 & 0,9 & & 1,0 & 1,0 \\
\hline $\begin{array}{l}\text { Organizational } \\
\text { abilities }\end{array}$ & 0,7 & 0,9 & 1,0 & & 1,0 \\
\hline $\begin{array}{l}\text { Management } \\
\text { practices }\end{array}$ & 0,7 & 0,9 & 1,0 & 1,0 & \\
\hline
\end{tabular}

The greater relative distance perceived by the specialists is in the pair "Creative Abilities" and "Administrative Practices", with weight of distance of 1,5. Three constructs point to similar utility function (1.0), which suggests equal weight 
(Expertise, Organizational Skills and Administrative Practices). This suggests a cluster of constructs with difficulty to be differentiated in importance.

This relation can be better observed by means of Figure 03, in which an interpolation is made between the three sub-levels used in the research. Level 1 (lowest $x$-axis value) is always zero because in comparison with any other higher level it becomes a dominated pair. The intermediate and high levels (respectively 2 and 3) of each construct present clearly divided behavior in three sets.

First, corroborating with the interpretation of the utility function obtained above, there is a clear cluster of three constructs (Expertise, Organizational Skills and Administrative Practices), with irrelevant variation along the curve in relation to one another. In the background, there is a separate intermediate curve equivalent to the Task Motivation construct. It should be noted that, however intermediate (when constructs are equally level intermediaries), there is a tendency to remain separate, but following the level of the first cluster. That is, the relative distance between the lowest cluster and Task Motivation remains comparatively constant.

Finally, the Creative Abilities construct is isolated. Their relative distance to the second construct tends to increase as both constructs are high. Or, if both Task Motivation and Creative Abilities are average, there is a greater preference for the latter, but when both are high, the preference for Creative Skills of the teams is enhanced, reaching a level of preferred preference.

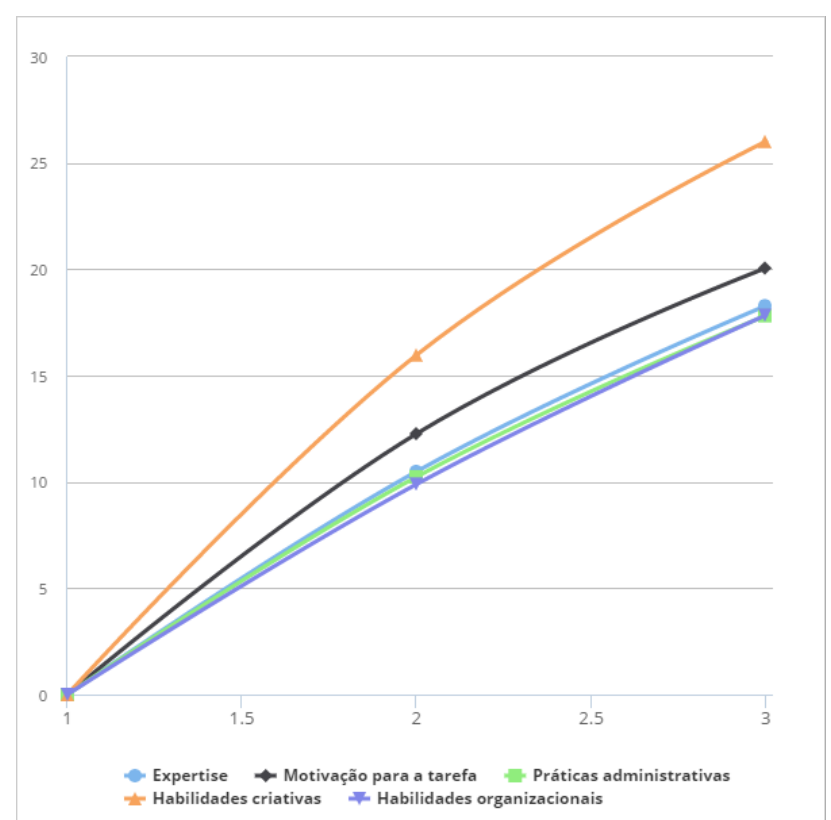

Figure 03: Interpolation in the weight of construct according to decision levels.

(Y-asix: preference percentage; $X$-axis: 1=low; 2=medium; 3=high)

Source: Elaboratedby authors. 
As such, it remains to deal with the hierarchy between the constructs (global importance of the same). It was possible to extract the average of the preferences of the decision makers regarding the positioning of each construct, described by means of Table 04.

Again, the information above corroborates with the acceptance of the model, in which there are three clusters of separate constructs. The first, lower in importance, brings together the Constructs Expertise, Organizational Skills and Administrative Practices (0.183, 0.178 and 0.178 respectively). The second cluster again presents the Construct Motivation for the Task (global importance of 0.201) and finally the construct considered more important, Creative Abilities (with global importance of 0.206).

Table 04 - Construct weights.

\begin{tabular}{|c|c|}
\hline Construct & $\begin{array}{c}\text { Weight } \\
\text { (total sum = 1) }\end{array}$ \\
\hline Creative abilities & 0,260 \\
\hline Task motivation & 0,201 \\
\hline Expertise & 0,183 \\
\hline Organizational abilities & 0,178 \\
\hline Management practices & 0,178 \\
\hline
\end{tabular}

Source: elaborated by authors.

Since each construct is separated by a specific weight, using existing scales in the literature, in the future one may try to create a measurement for organizational creativity for innovation based on the results obtained here. One suggestion is to create a framework with a measuring instrument based on the instrument developed by Lucato et al. (2012), in which assertions measure from the inexistence of the constructs until their full implementation in the corporate structure.

Another relevant aspect for practice is the difference between the weights obtained. This demonstrates that in addition to having an implicit preference, there is also a relative importance to the effort related to each construct and the expected result. That is, investing in teams that have creative skills and motivation for the task are expected to perform better than the managerial practice environment and the organization's ability to deliver the resources needed to implement the ideas generated by the creative process. The weight preferences of constructs also 
INDEPENDENT JOURNAL OF MANAGEMENT \& PRODUCTION (IJM\&P)

http://www.ijmp.jor.br

v. 8, n. 4, October - December 2017

ISSN: 2236-269X

DOI: 10.14807/ijmp.v8i4.643

demonstrate that innovative processes are intrinsically linked to individual capacities (even if grouped together) and interest in the work object regardless of how the organizational stimulus to task development occurs.

Weights and relationships between constructs suggest that companies with an innovative profile or that are in transition seeking to position themselves in this market need to undertake changes in their structures in order to accommodate projects focused on creative objectives, where the organizational structure fosters, promotes and enhances results Synergy of such creative teams.

\section{DISCUSSION}

Theoretical models tend to explain worldly phenomena by distinguishing internal features and how these are related to each other. That is, researchers are mostly concerned with conceptual delimitation as well as testing the reliability of their concepts (HINKIN, 1998; DEVELLIS, 2003). Fewer researchers delve deeper into understanding that the relationship between constructs is a simulacrum from reality and cannot be dissociated from real-world aspects (DIAMANTOPOULOS, 2005; SUDDABY, 2010).

Understanding the hierarchical relationship between constructs, on the other hand, is not simple, nor is it the focus of much of the research on creativity. However, it is a necessity in the theory to understand which criteria or constructs are more important than other (DIAMANTOPOULOS, 1999; DIAMANTOPOULOS; SIGUAW, 2006). As for creativity, as far as we could check, the models focus on the internal components, but do not seek finding which are more relevant. More importantly, practitioners may benefit from a practical approach to understanding creativity from an organizational standpoint.

The results allow some refining in this sense. First, one may see that there is indeed the possibility of hierarchically structuring creativity for organizational purposes. We found that individual-geared aspects still tend to be considered more relevant for creativity orientation towards innovation generation (see, for instance, Table 04). However, the fit between the task and the individual tasked with it is intrinsically organizational, and, as such, a matter of planning and strategic choice.

The organizational abilities and management practices ranked lower than individual/team traits, but there is not a huge gap between them. This demonstrates 
INDEPENDENT JOURNAL OF MANAGEMENT \& PRODUCTION (IJM\&P)

http://www.ijmp.jor.br

v. 8, n. 4, October - December 2017

ISSN: 2236-269X

DOI: 10.14807/ijmp.v8i4.643

that although highly capable individuals are still the core of innovation, the work environment is fundamental for these individuals to perform adequately - see the theory of flow (NAKAMURA; CSIKZENTMIHALYI, 2014).

Organizations still depend on creative individuals to generate innovations but start to perceive that geniuses are unpredictable and unreliable in the long run. As such, dependency on this kind of resource should be limited to the minimum necessary. Through managerial practices and work environment management innovation may come from teams instead of only individuals. Even in the case when creative individuals are requisites, team management still makes them more valuable as a starting point for organizational innovation generation, dissemination and response action (JAWORSKI; KOHLI, 1991).

\section{CONCLUDING REMARKS AND LIMITATIONS}

While research usually focuses on finding relevant concepts, analyzing them in conjunction and creating new theory, practical approaches to using scientific discovery are important sub-products. When it comes to creativity, most of the literature - and practitioners, for that matter - still fixates on highly capable individuals ('geniuses') as motors for innovation. However, depending on such human resources does not guarantee organizational motility towards idea generation and innovation implementation and finding and keeping them in an organization may prove costly, difficult to handle and unreliable.

As such, new research has come to light, focusing instead in team creativity and work environment that may assist in distributed creativity. It also aids in creating organizational mechanisms that allow creativity to flow, be better absorbed, but, more importantly, have tangible effects for an organization. Thus, these mechanisms may be moderators in the generation and dissemination of ideas, the generation of new organizational mechanisms for handling creativity and giving an organization tools for survival in its external environment.

This research aimed at finding whether these criteria (individual/team or work environment-related) may be hierarchically structured. As we showed it is possible and the hierarchical order found alters creativity processes in organizations. While the focus still is preeminent towards individuals, team and work management are not distantly related. However, since only a Brazilian sample was employed, other 
DOI: 10.14807/ijmp.v8i4.643

cultures or institutional environments may provide different hierarchies or different insights on how to handle creative individuals and teams.

\section{REFERENCES}

1000MINDS. (2015). 1000Minds software (PAPRIKA Method Implementation), Hansen \& Ombler.

ANDERSON, N.; POTOČNIK, K.; ZHOU, J. (2014). Innovation and Creativity in Organizations A State-of-the-Science Review, Prospective Commentary, and Guiding Framework. Journal of Management, v. 40, n. 5 p. 1297-1333.

AMABILE, T.; CONTI, R.; COON, H.; LAZENBY, J.; HERRON, M. (1996). Assessing the work environment for creativity. Academy of management journal, v. 39, n. 5, p. 1154-1184.

AMABILE, T. (1998). How to Kill Creativity. Harvard Business Review, n. 76, p. 7687.

AMABILE, T. (1997). Motivating creativity in organizations: on doing what you love and loving what you do. California management review, v. 40, n. 1, p. 39-58.

AMABILE, T. M.; PILLEMER, J. (2012). Perspectives on the social psychology of creativity. The Journal of Creative Behavior, v. 46, n. 1, p. 3-15.

BEDANI, M. (2012). O impacto dos valores organizacionais na percepção de estímulos e barreiras à criatividade no ambiente de trabalho. Revista de Administração Mackenzie, v. 13, n. 3.

BELTON, V.; STEWART, T. (2002). Multiple Criteria Decision Analysis: An Integrated Approach. Nova lorque: Springer.

BOADA-GRAU, J.; SANCHEZ-GARCIA, J. C.; PRIZNIC-KUZMICA, A. J.; VIGILCOLET, A. (2014). Spanish adaptation of the Creativity Potential and Practised Creativity scale (CPPC-17) in the workplace and inside the organization. Psicothema, v. 26, n. 1, p. 55-62.

CARTWRIGHT, D. (2013). Group dynamics and the individual. In: GIBSON, J.; HODGETTS, R. Readings and Exercises in Organizational Behavior. Londres: Academic Press.

CRONBACH, L.; MEEHL, P. E. (1955) Construct validity in Psychological Tests. Psychological Bulletin, v. 52, n. 4, p. 281-302.

DEVELLIS, R. F. (2003). Scale development: Theory and applications (2nd ed.). Thousand Oaks, CA: Sage.

DIAMANTOPOULOS, A. (1999). Viewpoint-export performance measurement: reflective versus formative indicators. International marketing review, v. 16, n. 6, p. 444-457.

DIAMANTOPOULOS, A. (2005). The C-OAR-SE procedure for scale development in marketing: a comment. International Journal of Research in Marketing, v. 22, n. 1, p. 1-9.

DIAMANTOPOULOS, A.; SIGUAW, J. A. (2006). Formative versus reflective indicators in organizational measure development: A comparison and empirical illustration. British Journal of Management, v. 17, n. 4, p. 263-282. 
DILIELLO, T.; HOUGHTON, J. (2008). Creative Potential and Practised Creativity: Identifying untapped creativity in organizations. Creativity and Innovation Management, vol. 17, n. 1.

DRAZIN, R.; GLYNN, M.; KAZANJIAN, R. (1999). Multilevel theorizing about creativity in organizations: a sensemaking perspective. Academy of management review, v. 24, n. 2, p. 286-306.

EKVALL, G. (1996). Organisational Climate for Creativity and Innovation. European Journal of Work and Organizational Psychology, v. 5, p. 105-23.

EKVALL, G. (1997). Organisational Conditions and Levels of Creativity. Creativity and Innovation Management, v. 6, p. 195-205.

FARID, F.; EL-SHARKAWY, A. (1993). Managing for creativity and innovation in $A / E / C$ organizations. Journal of Management in Engineering, v. 9, n. 4, p. 399409.

GARFIELD, M. J.; TAYLOR, N. J.; DENNIS, A. R.; SATZINGER, J. W. (2001). Research report: modifying paradigms-individual differences, creativity techniques, and exposure to ideas in group idea generation. Information Systems Research, v. 12, n. 3, p. 322-333.

GEORGE, J. (2007). Creativity in Organizations. The academy of management annals, v. 1, n.1, p. 439-477.

GERARD, H. (1954). The anchorage of opinions in face-to-face groups. Human Relations, v. 7, p. 313-325, 1954.

GIRDAUSKIENE, L. (2013). The key factors for creativity implementation and knowledge creation in an organization: the structural approach. Economics and management, v. 18, n. 1, p. 176-182.

GONCALO, J. A.; STAW, B. M. (2006). Individualism-collectivism and group creativity. Organizational behavior and human decision processes, v. 100, n. 1, p. 96-109.

HANSEN, P.; OMBLER, F. (2008). A new method for scoring multi-attribute value models using pairwise rankings of alternatives. Journal of Multi-Criteria Decision Analysis, n. 15, p. 87-107.

HINKIN, T. R. (1998). A brief tutorial on the development of measures for use in survey questionnaires. Organizational research methods, v. 1, n. 1, p. 104-121.

HIRST, G.; VAN KNIPPENBERG, D.; ZHOU, J. A. (2009). Cross-level perspective on employee creativity: Goal orientation, team learning behavior, and individual creativity. Academy of management journal, v. 52, n. 2, p. 280-293.

JASKYTE, K.; KISIELIENE, A. (2006). Determinants of employee creativity: a survey of Lithuanian non-profit Organizations. Voluntas, n. 17, p. 133-141.

JAWORSKI, B. J.; KOHLI, A. K. (1991). Supervisory feedback: Alternative types and their impact on salespeople's performance and satisfaction. Journal of Marketing Research, p. 190-201.

KAHNEMAN, D. (2011). Thinking - fast and slow. London: Macmillan. 
KOHLI, A.; JAWORSKI, B. (1990) Market Orientation: The Construct, Research Propositions, and Managerial Implications. Journal of Marketing, v. 54, n. 2, p. 118.

KÖKSALAN, M.; WALLENIUS, J.; ZIONTIS, S. (2011). Multiple Criteria Decision Making: From Early History to the 21st Century. Singapura: World Scientific.

KRUGLANSKI, A.W.; FRIEDMAN, I.; ZEEVI, G. (1971) The effects of extrinsic incentive on some qualitative aspects of task performance. Journal of Personality, v. 39 , p. $606-617$.

LARICHEV, O. (1992) Cognitive validity in design of decision-aiding techniques. Journal of Multi-Criteria Decision Analysis, v. 1, n. 3, p. 127-138.

LARICHEV, O.; MOSHKOVICH, H. (1997). Verbal Decision Analysis for Unstructured Problems. Boston: Kluwer Academic Publishers.

LARICHEV, O. (2001). Ranking multicriteria alternatives: The method ZAPROS III. European Journal of Operational Research, v. 131, n. 3, p. 550-558.

LUCATO, W. C.; VIEIRA JR., M.; VANALLE, R. M.; SALLES, J. E. (2012). Model to measure the degree of competitiveness for auto parts manufacturing companies. International Journal of Production Research, v. 50, n. 19, p. 5508-552.

MADJAR, N.; GREENBERG, E.; CHEN, Z. (2011). Factors for radical creativity, incremental creativity, and routine, noncreative performance. Journal of applied psychology, v. 96, n. 4, p. 730-743.

MARTIN, E.; TERBLANCHE, F. (2003). Building organizational culture that stimulated creativity and innovation. European Journal of Innovation Management, v. 6, n. 1, p. 64-74.

MARTINS, F. S.; VANALLE, R.; LUCATO, W. (2013) Coffee cooperatives' operation management: relevant factors for production diversification. In: 24th Annual POMS (Productions \& Operations Management Society) Conference, Denver, EUA, 2013.

MARTINS, F. S.; LUCATO, W. (2014) Economic trade-offs amongst production diversification strategies in Brazilian South-Eastern Coffee Cooperatives. Independent Journal of Management \& Production, v. 5, n. 1, p. 83-105.

MAXWELL, A.; JEFFREY, S.; LÉVESQUE, M. (2011) Business angel early stage decision making. Journal of Business Venturing, v. 26, n. 2, p. 212-225.

MCLEAN, L. D. (2005). Organizational culture's influence on creativity and innovation: a review of the literature and implications for human resource development. Advances in Developing Human Resources, v. 7, n. 2, p. 226-246.

MIRON-SPEKTOR, E.; EREZ, M.; NAVEH, E. (2011). The effect of conformist and attentive-to-detail members on team innovation: reconciling the innovation paradox. Academy of management journal, v. 54, n. 4, p. 740-760.

MOSHKOVICH, H.; MECHITOV, A. (2013). Verbal Decision Analysis: Foundations and Trends. Advances in Decision Sciences, v. 2013, article ID 697072, p. 1-9.

MOTLAGH, V.; HASSANI, M. (2013). Organizational formality and its relation with empowerment, innovation and creativity of the employees of education organizations: a case study. Life Science Journal, v. 10, n. 7, p.43-49. 
MOULTRIE, J.; YOUNG, A. (2009) Exploratory study of organizational creativity in creative organizations. Creativity and innovation management, v. 18, n. 4, p. 299314.

MULLER, R. C. (1993). Enhancing creativity, innovation and cooperation. Al \& Society, v. 7, n. p. 4-39.

NAKAMURA, J.; CSIKSZENTMIHALYI, M. (2014). The concept of flow. In Flow and the foundations of positive psychology (pp. 239-263). Springer Netherlands.

PARJANEN, S. (2012). Experiencing creativity in the organization: From individual creativity to collective creativity. Interdisciplinary Journal of Information, Knowledge, and Management, v. 7, p. 109-128.

PATTERSON, M. G.; WARR, P. B.; WEST, M. A. (2004). Organizational climate and company performance: the role of employee affect and employee level. Journal of Occupational and Organizational Psychology, v. 77, p. 193-216.

PAULUS, P. B.; YANG, H. C. (2000). Idea generation in groups: A basis for creativity in organizations. Organizational behavior and human decision processes, v. 82, n. 1 , p. $76-87$.

PERRY-SMITH, J. E. (2006). Social yet creative: The role of social relationships in facilitating individual creativity. Academy of Management journal, v. 49, n.1, p. 85101.

PUCCIO, G.; CABRA, J. (2010) Organizational creativity. In: KAUFMAN, J.; STERNBERG, R. The Cambridge Handbook of creativity, p. 145-173. New York: Cambridge University Press.

RUNCO, M. A.; SAKAMOTO, S. O. (1999). Experimental studies of creativity. In: Handbook of creativity, p. 62-92.

SAATY, T.; VARGAS, L. (2012). Models, Methods, Concepts \& Applications of the Analytic Hierarchy Process. New York: Springer.

SHALLEY, C. (1995). Effects of coaction, expected evaluation, and goal setting on creativity and productivity. Academy of Management Journal, v. 38, n. 2, p. 483503.

SHALLEY, C.; GILSON, L. (2004). What leaders need to know: a review of social and contextual factors that can foster or hinder creativity. The Leadership Quarterly, v. 15, n. 1, p. 33-53.

SOUSA, F.; PELLISSIER, R.; MONTEIRO, I. (2012). Creativity, innovation and collaborative organizations. The international journal of organization innovation, v. 5 , n. 1, p. 26-64.

STEELE, K.; CARMEL, Y.; CROSS, J.; WILCOX, C. (2009). Uses and misuses of multi-criteria decision analysis (MCDA) in environmental decision-making. Risk Analysis, v. 29, n. 1, p. 26-33.

STERNBERG, R. J. (2006). The Nature of Creativity. Creativity Research Journal, v. 18, p. 87-98.

STEWART, T. J. (2005). Dealing with uncertainties in MCDA, pp. 445-466. In: FIGUERA, J.; GRECO, S.; EHRGOTT, M. (Ed.) Multiple Criteria Decision Analysis, State of the Art Surveys. New York: Springer. 
SUDDABY, R. (2010). Challenges for institutional theory. Journal of Management Inquiry, 19(1), 14-20.

TORRANCE, E. P. (1988). The nature of creativity as manifest in its testing. The nature of creativity, p. 43-75.

TOUBIA, O. (2006). Idea generation, creativity, and incentives. Marketing Science, V. 25 , n. 5 , p. $411-425$.

TUORI, A.; VILÉN, T. (2011). Subject positions and power relations in creative organizations: taking a discursive view on organizational Creativity. Creativity and innovation management, v. 20 n. 2, p. 90-99.

WEST, M. A. (2000). State of the art: Creativity and innovation at work. Psychologist, v. 13, n. 9, p. 460-464.

WESTWOOD, R.; LOW, D. R. (2003). The multicultural muse - culture, creativity and innovation. International journal of cross cultural management, v. 3, n. 2, p. 235-259.

WONGTADA, N.; RICE, G. (2008). Multidimensional latent traits of perceived organizational innovation: differences between Thai and Egyptian employees. Asia Pacific Journal of Management, v. 25, n. 3, p. 537-62.

WOODMAN, R. W.; SAWYER, J. E.; GRIFFIN, R. W. (1993). Toward a theory of organizational creativity. Academy of management review, v. 18, n. 2, p. 293-321.

ZHANG, W.; ZHANG, Q.; YU, B.; ZHAO, L. (2015). Knowledge map of creativity research based on keywords network and co-word analysis, 1992-2011. Qual Quant, v. 49, p. 1023-138.

ZHOU, J.; SHALLEY, C. E. (2008) Handbook of Organizational Creativity. New York: Taylor \& Francis Group. 